\title{
Generation of Bio-fuel by Using Waterweeds: A Case Study in Solapur City
}

Avinash Kishor Shendge* and Basavraj Balapgol

Division of Environmental Engineering, Department of Civil Engineering, DYPCO, Savitribai Phule Pune University, Maharashtra, India

\begin{abstract}
The production of large quantities of bio mass of aquatic floating species especially waterweeds, during the aquatic phase of the flood-pulse characteristics for this ecosystem. Such bio mass could be wisely managed for the production of bio fuels. The aquatic biomass exploitation would require low fossil energy and material inputs leaving a positive energy balance, white minimal interference in the environment. And it is relatively less flammable as compared fossil diesel. It is significantly reduced level of particulate matter emission and also less harmful carbon emission. Currently biodiesel is becoming popular as an environmental friendly fuel. It has been used as in the automotive industry. A major source of energy for our society is the burning of fossil fuels such as coal, petroleum and natural gas. But these sources are found out to be in the limited amounts of available, so those are depleting resources. Bio fuel is much better lubricant than petro diesel and extends engine life. An attempt was made to produce biodiesel from water weeds and discuss technical, socio-economic, and environmental benefits of small scale biofuels such as improving energy access, generation and mitigating environmental pollution at both local and global levels. The obtained result indicated that waterweeds sample should variable sugar content (for $30 \%$ of $\mathrm{H}_{2 \mathrm{~S}} \mathrm{O}_{4}$ sample) is $1 \%$ to $1.2 \%$ and Alcohol content should found $2 \%$ to $2.4 \%$ from $1.5 \mathrm{~kg}$ of waterweeds sample. Thus the study has demonstrated systematic approach to disposal of water weeds in solid waste management system. Biodiesel and bio-ethanol production is an alternative approach to fossil fuel.
\end{abstract}

Keywords: Bio-fuel; Bio-mass; Waterweeds; Trans-esterification

\section{Introduction}

The main goals of developing the biofuels sector are sustainability. The sustainability depends upon the three pillars of economic, social and environmental sustainability. In economic terms, biofuels production has to be cost effective and competitive than petroleum. In social terms, biofuels development can create new demand in the agricultural economy [1-6]. As biofuels production is an agricultural process, the same elements and inputs contribute to its overall efficiency as for existing agricultural production systems. In environmental sustainability term, biofuel production does not hazard to environment.

According to the latest official statistics, global production of biofuels reached a record level of over 34 Mtoe in 2007 accounting for $1.5 \%$ of total road related fuel consumption. Preliminary figures for 2008 suggest the total production increase to nearly 39 Mtoe.

Global depletion of energy supply due to continuing over-utilization is a major problem of the present and future world community. The continuous depletion of fossil fuel reserves and consequent escalation in their price has stimulated interest in development of alternative technologies and substrates to meet the global energy demand.

\section{Different source of biofuels}

Algae-Green growth originate from stale lake in the regular world and all the more as of late in green growth ranches, which deliver the plant for the particular motivation behind making biofuel preferred stand point of green growth focused on the following: $\mathrm{NO}, \mathrm{CO}_{2}$ into the air, self-crating biomass [7].

\section{Carbohydrate rich material}

It originate from the aging of starches got from agrarian items like corn, sugar, sticks, wheat, beets etc...or from unappetizing cellulose from the same. Created from existing yields can be utilized as a part of a current gas motor making it a sensible progress from oil [8].

\section{Oil rich material}

It originates from exiting sustenance crop like rapeseeds, sunflower, corn and other. Not powerless to microbial debasement, high accessibility, reutilized material. It is utilized as a part of making of biodiesel fuel automobiles, home heating, etc. [9].

\section{Agriculture waste}

It originates from agriculture waste which is gathered into charcoal like biomass by heating it. Next to no handling required and normally holds $\mathrm{CO}_{2}$ as opposed to discharging it into the air.

\section{Background and Case Study}

In the year 2012-13 India imported 184.795 MMT petroleum of $7,84,652$ crores. The import of petroleum increased by $7.61 \%$ in the year, 2012. Due to fall in rupee value the cost increased by $16.73 \%$ in US dollars the increase in petroleum crude oil import was increased by $3.30 \%$ [10]. Now the present growth is $7.13 \%$ as compared to the year 2012 (Figure 1).

The Lake Sambhaji is located on the Solapur-Bijapur highway at Solapur city. The lake type is semi natural lake. The catchment watershed area is $0.2177 \mathrm{sq} \mathrm{km}$. The nature of the lake is however plain. The lake is used for recreation, washing/Laundry, solid waste, sewerage has not been provided yet and there is no sewage treatment followed.

\section{Diesel}

Diesel is a fractional distillate of crude petroleum between $200^{\circ} \mathrm{C}$ to

"Corresponding author: Shendge AK, Division of Environmental Engineering, Department of Civil Engineering, DYPCO, Savitribai Phule Pune University, Maharashtra, India, Tel:+91 02027653054; E-mail: ak.shendge@gmail.com

Received July 07, 2018; Accepted July 18, 2018; Published July 25, 2018

Citation: Shendge AK, Balapgol B (2018) Generation of Bio-fuel by Using Waterweeds: A Case Study in Solapur City. J Pet Environ Biotechnol 9: 375. doi: 10.4172/2157-7463.1000375

Copyright: (C) 2018 Shendge AK, et al. This is an open-access article distributed under the terms of the Creative Commons Attribution License, which permits unrestricted use, distribution, and reproduction in any medium, provided the original author and source are credited. 


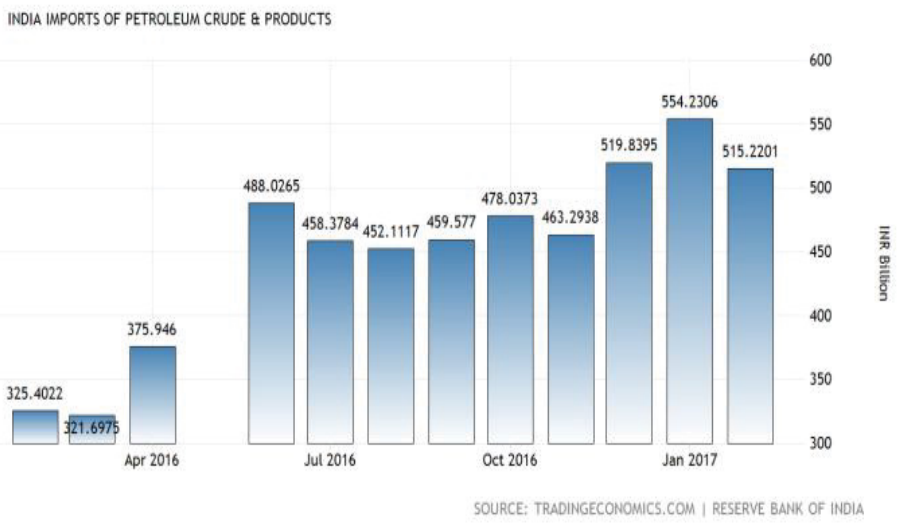

Figure 1: Import of petroleum crude and products in India.

$350^{\circ} \mathrm{C}$ at 1 atm pressure. Diesel contains hydrocarbons between 8 to 21 Carbons per molecule. As per European road diesel EN 590 standard minimum certain number of diesel must be 51 . The density of diesel must be $0.832 \mathrm{~kg} / \mathrm{L}$. $73.25 \mathrm{~g} / \mathrm{MJ}$ Carbon dioxide emissions. Heat of Combustion is $43.1 \mathrm{MJ} / \mathrm{kg}$. The petroleum crude oil contains paraffinic compounds, Napthenic compounds and aromatic compounds. Alkanes and cycloalkanes groups are present in diesel.

\section{Biodiesel quality assessment}

The principle measure of diesel quality is based on its cetane number; higher cetane number fuel ignites rapidly, when they are sprayed inside hot compressed air. The high cetane number improves combustion and cold starting. The noise and emission is also reduced by high cetane fuel.

1. Knocking is the explosion of fuel inside engine.

2. Anti-knocking agents are substances that decreases knocking of fuel, used in high performance engines.

3. Octane number also known as octane rating, it is a standard measure of anti-knock properties and performance of motor and jet fuel. The high octane rate fuels can withstand high compression. Higher octane fuels have high performance.

4. Pour point of diesel is the lowest temperature at which it forms a semi solid fluid and its flow properties are altered. The high pour point indicates higher paraffin content of the fuel.

5 . Kinematic viscosity is a ratio of the dynamic viscosity and density of a fluid $\left(\mathrm{m}^{2} / \mathrm{s}\right)$.

6. Cloud point is the temperature at which dissolved solids in diesel starts precipitating.

7. Acid value of diesel is the amount of potassium hydroxide used in neutralizing one gram of diesel.

\section{Parametric Investigations}

\section{Determination of $\mathrm{pH}$}

Chemical required: Buffer tablet of $\mathrm{pH}$ values 4 and 9.2

Reagents preparation: Buffer tablet of $\mathrm{pH}$ value 4 is dissolved in $100 \mathrm{ml}$ of distilled water. This solution should preferably be stored in a plastic bottle in cool place. Buffer tablet of $\mathrm{pH}$ value 9.2 is dissolved in $100 \mathrm{ml}$ of distilled water (Tables 1-7).

\begin{tabular}{|c|c|c|c|}
\hline S. No. & Name of Test & Unit & Reading \\
\hline 1. & $\mathrm{pH}$ & - & 4.6 \\
\hline 2. & Turbidity & NTU & 13.6 \\
\hline 3. & DO & $\mathrm{mg} / \mathrm{l}$ & Nil \\
\hline 4. & COD & $\mathrm{mg} / \mathrm{l}$ & 68 \\
\hline 5. & BOD & $\mathrm{mg} / \mathrm{l}$ & 30.6 \\
\hline
\end{tabular}

Table 1: Results of water sample 1.

\begin{tabular}{|c|c|c|c|}
\hline S. No. & Name of Test & Unit & Reading \\
\hline 1. & $\mathrm{pH}$ & - & 4.9 \\
\hline 2. & Turbidity & $\mathrm{NTU}$ & 27 \\
\hline 3. & DO & $\mathrm{mg} / \mathrm{l}$ & $\mathrm{Nil}$ \\
\hline 4. & COD & $\mathrm{mg} / \mathrm{l}$ & 97 \\
\hline 5. & BOD & $\mathrm{mg} / \mathrm{l}$ & 42 \\
\hline
\end{tabular}

Table 2: Results of water sample 2.

\begin{tabular}{|c|c|c|c|}
\hline S. No. & Name of Test & Unit & Reading \\
\hline 1. & $\mathrm{pH}$ & - & 4.4 \\
\hline 2. & Turbidity & $\mathrm{NTU}$ & 20.5 \\
\hline 3. & DO & $\mathrm{mg} / \mathrm{l}$ & $\mathrm{Nil}$ \\
\hline 4. & COD & $\mathrm{mg} / \mathrm{l}$ & 72 \\
\hline 5. & BOD & $\mathrm{mg} / \mathrm{l}$ & 32 \\
\hline
\end{tabular}

Table 3: Results of water sample 3.

\begin{tabular}{|c|c|c|c|}
\hline S. No. & Name of Test & Unit & Reading \\
\hline 1. & $\mathrm{pH}$ & - & 5.6 \\
\hline 2. & Turbidity & $\mathrm{NTU}$ & 18 \\
\hline 3. & DO & $\mathrm{mg} / \mathrm{l}$ & $\mathrm{Nil}$ \\
\hline 4. & $\mathrm{COD}$ & $\mathrm{mg} / \mathrm{l}$ & 68 \\
\hline 5. & BOD & $\mathrm{mg} / \mathrm{l}$ & 31 \\
\hline
\end{tabular}

Table 4: Results of water sample 4.

\begin{tabular}{|c|c|c|c|}
\hline S. No. & Name of Test & Unit & Reading \\
\hline 1. & $\mathrm{pH}$ & - & 6.56 \\
\hline 2. & Turbidity & $\mathrm{NTU}$ & 28.8 \\
\hline 3. & DO & $\mathrm{mg} / \mathrm{l}$ & $\mathrm{Nil}$ \\
\hline 4. & COD & $\mathrm{mg} / \mathrm{l}$ & 93 \\
\hline 5. & BOD & $\mathrm{mg} / \mathrm{l}$ & 41.8 \\
\hline
\end{tabular}

Table 5: Results of water weed sample.

\section{Procedure}

a) Wash the combined electrode of $\mathrm{pH}$ meter with distilled water. 
Citation: Shendge AK, Balapgol B (2018) Generation of Bio-fuel by Using Waterweeds: A Case Study in Solapur City. J Pet Environ Biotechnol 9: 375. doi: $10.4172 / 2157-7463.1000375$

Page 3 of 4

\begin{tabular}{|c|c|c|c|c|}
\hline \multirow{2}{*}{ S. No } & $\begin{array}{c}\text { Waterweed } \\
\text { Sample }\end{array}$ & $\begin{array}{c}\text { Unit for } \\
\text { TRS and } \\
\text { Alcohol }\end{array}$ & $\begin{array}{c}\text { Total } \\
\text { Reducing } \\
\text { Sugar }\end{array}$ & Alcohol \\
\hline \multirow{2}{*}{1.} & Sample A & $\%$ & 0.12 & 0.45 \\
\hline \multirow{2}{*}{2.} & Sample B & $\%$ & 0.15 & 0.55 \\
\cline { 3 - 5 } & & $\%$ & 0.1 & 0.56 \\
\hline
\end{tabular}

Table 6: TRS and alcohol of water weeds sample 1.

\begin{tabular}{|c|c|c|c|c|}
\hline S. No & $\begin{array}{l}\text { Waterweed } \\
\text { Sample }\end{array}$ & $\begin{array}{l}\text { Unit for } \\
\text { TRS and } \\
\text { Alcohol }\end{array}$ & $\begin{array}{l}\text { Total } \\
\text { Reducing } \\
\text { Sugar }\end{array}$ & Alcohol \\
\hline \multirow{2}{*}{3} & \multirow{2}{*}{$\begin{array}{l}\text { Sample A with } \\
5 \% \mathrm{H}_{2} \mathrm{SO}_{4}\end{array}$} & $\%$ & 0.2 & 0.5 \\
\hline & & $\%$ & 0.25 & 0.48 \\
\hline \multirow{2}{*}{4.} & \multirow{2}{*}{$\begin{array}{l}\text { Sample B with } \\
10 \% \mathrm{H}_{2} \mathrm{SO}_{4}\end{array}$} & $\%$ & 0.6 & 0.98 \\
\hline & & $\%$ & 0.75 & 1.2 \\
\hline \multirow{2}{*}{5.} & \multirow{2}{*}{$\begin{array}{l}\text { Sample A with } \\
20 \% \mathrm{H}_{2} \mathrm{SO}_{4}\end{array}$} & $\%$ & 0.8 & 1.8 \\
\hline & & $\%$ & 0.84 & 1.9 \\
\hline \multirow{2}{*}{6.} & \multirow{2}{*}{$\begin{array}{c}\text { Sample A with } \\
30 \% \mathrm{H}_{2} \mathrm{SO}_{4}\end{array}$} & $\%$ & 1 & 2 \\
\hline & & $\%$ & 1.2 & 2.4 \\
\hline
\end{tabular}

Table 7: TRS and alcohol of water weeds sample 2.

b) Dip the combined electrode in the buffer solution of $\mathrm{pH}$ value 4 and 9.2 .

c) Adjust the temperature by the adjustment knob to an ambient (room) temperature.

d) If the instrument shows the reading as 4 and 9.2 respectively then it is in order if not, adjust the reading to 4.0 and 9.2 by calibration adjustment knob.

e) Repeat the above procedure until the meter shows reading as 4 and 9.2 respectively when electrode is dip in buffer solution.

\section{Turbidity}

Chemicals required: Dissolve $1.0 \mathrm{~g}$ Hydrazine sulphate and dilute to $100 \mathrm{ml}$, Dissolve $10 \mathrm{~g}$ Hexamethylene Tetramine and dilute in $100 \mathrm{ml}$, take $5 \mathrm{ml}$ of each of the above solution ( 1 and 2) in a $100 \mathrm{ml}$ volumetric flask and allow standing for $24 \mathrm{~h}$ at $25 \pm 3^{\circ} \mathrm{C}$ and diluting to $1000 \mathrm{ml}$. This solution has a turbidity of 40 NTU.

\section{Procedure}

a) Calibration of Nephelometer is done by using above reagent.

b) The sample is thoroughly shake and kept it for sometimes so the air bubbles are eliminated.

c) The sample is taken in Nephelometer tube and the sample is put in chamber and the reading is noted directly.

\section{Determination of dissolved oxygen}

Chemical required: Sodium hydroxide, Manganous sulphate, Potassium iodide, Sodium thiosuiphate, Conc. $\mathrm{H}_{2} \mathrm{SO}_{4}$ and starch.

\section{Procedure}

a) Take $50 \mathrm{ml}$ of clear pipette solution in a conical flask

b) Add to it one or two drops of starch indicator until the color becomes blue.

c) Titrate against Standard Sodium Thiosulphate solution until the disappearance of color. d) Repeat the titration for concordant value

\section{Determination of COD}

Chemical required: Potassium dichrornate, Conc. Sulphuric acid, Ferroin indicator solution, Std. Ferrous ammonium sulphate solution and Mercuric Sulphate.

\section{Procedure}

a) Take $50 \mathrm{ml}$ of sample in a flask and $1 \mathrm{~g}$ of $\mathrm{HgSO}_{4}$ and $5 \mathrm{ml}$ of $\mathrm{H}_{2} \mathrm{SO}_{4}$ add slowly to dissolve $\mathrm{HgSO}_{4}$ and cool the mixture.

b) Add $25 \mathrm{ml}$ of $0.25 \mathrm{~N} \mathrm{~K}_{2} \mathrm{Cr}_{2} \mathrm{O}_{7}$ solutions. Attach the condensate and start the cooling water. Apply the heat and reflux for $2 \mathrm{~h}$.

c) Dilute the mixture to about $300 \mathrm{ml}$ and titrate excess dichromate with std. FAS using Ferroin indicator. red.

d) The color will change from yellow to green to blue and finally

e) Reflux on the same manner to a flask consisting of distilled water, equal to the volume of the sample and the reagents titrate as he sample and $\mathrm{ml}$ of titrant was deduced.

\section{Total reducing sugar}

Chemical required: Leading solution, De-leading solution, HCL, Phenophelin indicator, $\mathrm{NaOH}$, Fehling A and Fehling B.

\section{Procedure}

a) Take $12.5 \mathrm{~g}$ raw material taken $+25 \mathrm{ml}$ leading solution $+250 \mathrm{ml}$ distilled water.

b) All solution Swills filtered and $50 \mathrm{ml}$ solution will take $+10 \mathrm{ml}$ de leading solution added $=250 \mathrm{ml}$ distil water.

c) After that take $50 \mathrm{ml}$ filtered $+5 \mathrm{ml} \mathrm{HCL}$ added, then heat at 680 in water bath cool down room temperature then added 2 to 3 drop phenophelin indicated and neutral with 6 normal $\mathrm{NaOH}$ and make up $100 \mathrm{ml}$ with distil water [pink color form] fill in burette.

d) In conical flask $-5 \mathrm{ml}$ Fehling $\mathrm{A}+5 \mathrm{ml}$ Fehling $\mathrm{B}+10 \mathrm{ml}$ distilled water. 


\section{e) End point brick red color}

Percentage of sugar $=5.128$ (standard value of Fehling of sugar) $/$ burette reading $\mathrm{x}$ dil. factor (0.05) x Fehling factor (0.9323).

\section{Alcohol}

\section{Procedure}

a) Take $50 \mathrm{ml}$ sample $+50 \mathrm{ml}$ water $=100 \mathrm{ml}$.

b) Assemble in distilled and take $50 \mathrm{ml}$ sample collected.

c) It will take pycnometer.

d) Take empty weight of pyconometer then take weight of Pyconometer + sample A.

e) Again take a weight of Pyconometer + sample B.

f) Ratio will check in chart alcoholic.

1. $\mathrm{COD}$ and $\mathrm{BOD}$ value is maintained according to cell structure. If the value of $\mathrm{COD}$ and $\mathrm{BOD}$ will be more then it is diluted with fresh water. More $\mathrm{COD}$ and $\mathrm{BOD}$ values shows more contaminate.

2. $\mathrm{pH}$ is adjusted to near 4 to 5 in acidic condition because it will helpful in fermentation process.

3. It is seen that the sample is in acidic condition at the final stage of production.

4. The obtained result indicated that waterweeds sample should variable sugar content (for $30 \%$ of $\mathrm{H}_{2} \mathrm{SO}_{4}$ sample) is $1 \%$ to $1.2 \%$ and Alcohol content should found $2 \%$ to $2.4 \%$ from $1.5 \mathrm{~kg}$ of waterweeds sample.

\section{Conclusions}

1. Water weeds are one of the unfavorable weeds causing the major problem to the aquatic ecosystem. Although preventive measures to control its population have been widely applied including use of herbicides and mechanical removal, in most of the cases [3].

2. In present investigation, water in the lake is highly polluted so that sewerage system is developed near surrounding area. And also strong legislation will be enforced for breaking rules and regulation.

3. The technique described above helps lowering the plant population while providing a simple and low-cost process, Where the cellulose portion of the herbs are hydrolyzed by enzymes into glucose sugar that are fermented to bioethanol [11].

4. The sugars from the hemicellulose are also fermented to bioethanol. Many studies were done about pre-treatment process. A number of methods were developed for this purpose, so that focusing on physical, chemical or biological processes. To get green ethanol, we must concentrate on biological process for pre-treatment and fermentation [11]. The main issue in biological process is that it is time consuming.

\section{Recommendations}

Study of generation of biofuel is plays very important role. It is now accepted fact that the basic reason behind all environmental problems is human greed for more profits [12]. This resulted in heavily polluted air, water, land and soil. So certainly government and NGO have to play significant role for creating public awareness which is very useful to save environment.

India is in developing stage and this is the right time to work on sustainable development. Using $3 \mathrm{R}$ formula we can contribute towards sustainable development at individual level. A greater depth of knowledge in terms of RS \& GIS analytical techniques is necessary to progress independently for the future studies. Government has undertaken numbers of Sewerage disposal system (Swachh Bharat Mission) projects all over the country. If government adopted this sustainable development, surely we can develop Smart Cities in India [6]. Above recommendations have various benefits for both citizen as well as Government.

\section{Future Scope}

Water weeds are mixed with a plenty of molasses to increase sugar content for best result in biodiesel production. We can further go for such project with in Partnership with Private Players. Government should provide subsidies to those existing societies who incorporate with biofuel production for their societies.

\section{Acknowledgements}

Author would specially like to thanks Dr. B. S. Balapgol (Principal - D. Y. Patil Pune), for his valuable inputs from time to time. Author would like to thank Prof Sachin J. Mane (P.G. Coordinator - Civil Engineering Department, D. Y. Patil Pune) for their guidance and reviews.

\section{References}

1. Fagan JM (2015) Converting problematic aquatic plants to biofuel. Biocycle Magazine.

2. Simhadri K, Sai Chaitanya P, Mohan GVD (2015) Experimental analysis on performance improvement of diesel engine utilizing alternate fuels. IOSRJMCE 12: 8-13.

3. Bhakta JN, Ohnishi K (2015) Bio fuel potential of aquatic weeds. Int J Env Tech Sci 1: 15-20.

4. Bhakta JN (2004) Biofuel potential of waterweeds. Int J Env Tech Sci 1: 15.

5. Ganguly A, Chatterjee PK, Dey A (2011) Studies of ethanol production from water Hyacinth - A review. ऐ Renew Sustain Energy 16: 966- 972.

6. Sagar V, Kumari AN (2013) Sustainable biofuel production from water Hyacinth (Eicchornia crassipes). IJETT 4: 4454-4458

7. Bergier I, Suzana MS, César HBM, Ortega E, Luengo CA (2012) Biofue production from water hyacinth in the Pantanal wetland 12: 77-84.

8. Bentley RW (2002) Global oil and gas depletion: An overview. Energy Policy 30: 189-205.

9. Bhattacharya A, Kumar $P$ (2010) Water hyacinth as a potential biofuel crop Elec J Environ Agric Food Chem 9: 112-122.

10. Cavallo AJ (2002) Predicting the peak in world oil production. Nat Resources 11: 187-195.

11. Sepehri A (2018) Effect of nitrifier community on fouling mitigation and nitrification efficiency in a membrane bioreactor. Chem Eng Process 128: 10-18.

12. Carlo NH (2005) Outlook for advanced biofuels. Energy Policy 34: 368-383. 